\title{
Logistic approach to intellectual property
}

\author{
Olga Kalinina ${ }^{l, *}$, Larisa Alekseeva ${ }^{2}$, Daria Varlamova $^{2}$, Sergey Barykin ${ }^{3}$, and Irina \\ Kapustina ${ }^{4}$ \\ 1,5Peter the Great St. Petersburg Polytechnic University, Polytechnicheskaya, 29, 195251, St. \\ Petersburg, Russian Federation \\ ${ }^{2,3}$ Saint Petersburg National Research University of Information Technologies, Mechanics and Optics \\ (ITMO University), Kronverksky Pr. 49, 197101, St. Petersburg, Russian Federation \\ ${ }^{4}$ Selectel Ltd., Str. Tsvetochnaya 21, lit. A, 196084, Saint-Petersburg, Russian Federation
}

\begin{abstract}
In the age of economy's digitalization, the importance of intangible assets in the activity of enterprises increases, which is caused by the content of fundamental trends, according to which the behavior of economic entities and their way of functioning transform into a new operating model of companies, especially in banking and telecommunications sectors, aimed at increasing cost efficiency and identification of new opportunities in the market mainly on the basis of methods of analysis of large amounts of data to generate new knowledge and make effective management decisions. Accordingly, in the conditions of economy's digitalization, intellectual property starts to play more and more significant role as a backbone asset of enterprises, causing development of the intellectual property market and the need to formalize its operation and create an efficient infrastructure for the market. This article discusses the issue of intellectual property objects' turnover in the Russian economy in the conditions of digitalization with funds being invested into specific energy project.
\end{abstract}

\section{Introduction}

Information and digital economy have got the following main features: global nature, network principles of society and markets coordination and transactions with intangible benefits like information, relationships and ideas. The technological ground of the modern digital economy is formed on the basis of achievements of the fourth industrial revolution [12]. The most important of them are distributed data, artificial intelligence, Internet of things, blockchain, big data, digital platforms, cloud storage, 3D- and later 4D-printing [3]. In 2014, FORTUNE magazine covered an example of 3D printing for manufacturing, "General Electric's Leap jet engine is not only one of the company's bestsellers, it's going to incorporate a fuel nozzle produced entirely through additive manufacturing. The process, popularly known as 3D printing, involves building up layers of material (in this case alloyed metals) according to precise digital plans.

In smart cities, various services, utilities and roads are connected to the Internet [4] to manage the flow of energy, materials, logistics and traffic. State-of-the-art cities like Singa-

\footnotetext{
* Corresponding author: olgakalinina@bk.ru
} 
pore and Barcelona have already been implementing various data-collection services, including "smart" car parking solutions and "smart" garbage collection processes [5].

Here are the positive properties of smart cities development [6]:

- more efficient use of resources;

- productivity growth;

- improving the quality of life;

- improving access to resources for the entire population;

- cost of services reduction;

- increased transparency regarding the use and status of resources;

- lower crime level;

- increased mobility;

- decentralized climate-friendly energy production and consumption;

- decentralized production of goods;

- increased resistance (to climate changes);

- lower pollution levels (air pollution, noise protection).

Today, more and more people move to live in cities (at the end of 2018 more than a half of global population of 7.5 billion people lived in cities). Rising energy consumption in the cities leads to an increased environmental pollution [7-8] and global warming [9].

\section{Materials and Methods}

The digital economy growing on the ground of the information economy, can be described as a "continuation in a new capacity after an unprecedented and disruptive technological breakthrough as a result of the fourth industrial revolution, which is characterized by nonlinear (exponential) rising speed of innovations, depth and scale of digital technologies penetration and powerful influence of digital complexes and systems." Digital systems and complexes significantly change decisions motivation as well as a way of thinking, i.e. not only productivity changes, but economic behavior, principles of organization and functioning of companies and the economic framework in general.

One should consider the interrelation between environmental degradation and use of energy and natural resources. In order to avoid global environmental crisis due to consumption which rises as well as energy production, a new qualitative level goods and services consumption and production should be reached in the frames of new digital economy, what could be studied in the concept of the sharing economy [13]. The fundamentals of the research in the scientific field of energy-saving project could be examined with the methodology of logistic theory considered by famous scientists in a specific area having been developed as multi-directional scientific research with financial management theory and methods of logistics [14-16]. The following features are essential:

1) it is necessary to simultaneously solve a number of different tasks related to the most distant from each other scientific disciplines;

2) the methods of both financial management and logistics theory are implemented taking into account the specific problem of integrating the material and accompanying financial flows;

3) the subject of the study of financial logistics includes the problem solved in the research system by the means of transition from abstract theoretical schemes to obtaining results specified by the frames of energy saving projects in the digital economy.

Digitalization is a fundamental trend of modern economy's development, based on the active use of digital technologies in the activity of enterprises.

Digitalization has influenced the following aspects of doing business:

- ways of conducting and organizing business, long-term marketing strategies;

- algorithms of resource support of business; 
- the amount and structure of production and transaction costs (organizational, management, communication costs, costs for receiving information, its processing and storage) are falling or even disappearing in digital environment; - scale and network effects, which are becoming global.

Collaborative innovations are a new form of cooperation between economic entities in the digital economy. This form of cooperation appeared due to the rapid emergence of innovations and their growing disruptive impact. Enterprises in the framework of collaboration combine various resources, jointly implementing innovative projects. Such integration of capabilities leads to synergistic effects.

Environmental responsibility of economic entities becomes an important image characteristic of business. Goodwill, a set of intangible assets of the organization, including brand, reputation, customer base, etc. can be considered as a factor of image. The environmental component of intangible assets can serve as a basis for building business reputation of the enterprise in the field of environmental safety, which, in turn, will increase the cost of assets, as well as a number of government benefits or the possibility of accelerated depreciation in case of financing energy saving and other environmental innovations. Thus, ecology and energy saving initiative will provide additional benefits to the enterprises both in the business environment and government support. The concept of managers' proactive and "smart" thinking suggests that today's environmental actions can benefit future generations [10]. Financial market instruments are the drivers of progress of environmental innovation. And commercial banks are the main participants of the market. Banks acting as financial intermediaries, have sufficient investment potential to finance environmental projects. The banking sector acting as lifeblood of economy is able to influence the national vector of ecological and economic development.

The banking community develops the following aspects of environmental positioning, taking into account both the work with contractors (external ties) and organizational business processes (internal ties).

First aspect is environmental projects financing. Being environmentally neutral, the banking sector has historically been playing the role of intermediary between various economic agents, while relying on rigid and formal approaches. The banks through environmental projects support can flatten the balance between economic development and human habitat protection. Therefore, by giving priority to socially responsible clients, financial intermediaries strengthen their own reputation and contribute to the formation of Industry 4.0 pure digital technologies.

The second aspect is "green" banking products. Commercial banks together with business partners become initiators of "green" card programs. Thus, the alliance with nature protection funds gives banks the opportunity to declare their value points to stakeholders, to strengthen their image and involve banking environment into socially significant projects. An example of such activity of the banks is the issuance of affinity-cards, when the bank transfers part of the fee for card transactions in favor of a charitable organization. Affinityprocedures allow both the bank and its clients to feel socially responsible subjects of the market.

The above aspects of environmental positioning characterize the external environmental activity of banks. As a rule, this activity is aimed at reducing the effects of adverse anthropogenic and man-made factors and at preventing possible adverse impacts on the ecosystem. 
Internal processes imply harmful environmental impact reduction from direct activity of the banks themselves. Heat-saving technologies and energy-saving lamps reduce the volume of heat and electricity consumption, and sensor water taps reduce water consumption. Rational use of consumables, proper waste disposal, paperless workflow, landscaping of the territory near the bank, "green" offices construction can also have a significant impact on environment.

\section{Results}

In order to profit from digital technology, businesses have to change their operating models radically and improve their flexibility and mobility. A new operating model that practices shared use represents a platform. The platform method is based on the network effect happening when business goes digital. With the beginning of the fourth industrial revolution, global platforms have emerged that are closely linked to the physical world.

Thus, digital economy's operation is based on active use of intellectual property. Unique technologies, techniques, research developments existing in the form of useful models, inventions, trademarks, industrial designs, know-how belonging to the category of objects of intellectual property, all these can become a significant competitive advantage of the company. In this regard, in the conditions of economy's digitalization intellectual property objects become key assets for an increasing number of economic entities.

Intellectual property is a collective term: it includes the exclusive rights of individuals and legal entities to the results of intellectual activity and the equivalent means of individualization of the legal entity, products, works or services provided.

Intellectual property objects are divided into the following categories (Error! Reference source not found.):

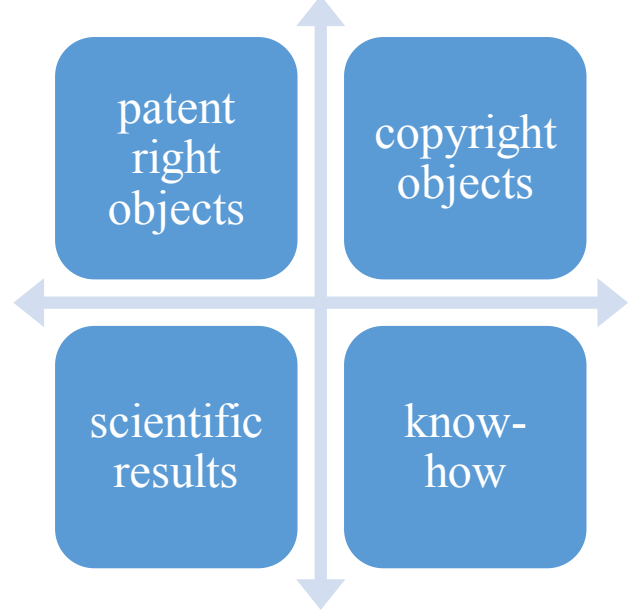

Fig. 1. Block diagram of Intellectual Property Objects

The main indicators of the IP market's development are, as a rule, its quantitative characteristics, - the number of patent and trademark applications and the number of registrations made. The progress, according to common practice and WIPO's assessment, is in the growth of these indicators. Registration statistics can only provide a rough picture of the situation on the IP services market, which in turn can raise theoretic conclusions about the place and role of IP in the economy of the correspondent states.

The number of applications for registration of intellectual property objects (IPO's) in the world and in Russia for the year of 2018 could be compared as follows (Error! Reference 
source not found.). In 2018, about 2.9 million patent applications were filed globally, the majority of applicants were from China, applicants from the United States were the next in the list [12].

Table 1. Number of applications for registration of intellectual property objects (IPO's) in the world and in Russia

\begin{tabular}{|l|c|c|}
\hline Objects of intellectual property & Globally & In Russia \\
\hline Patents & 2888800 & 45835 \\
\hline Trademarks & 8445300 & 562100 \\
\hline Industrial designs & 1144800 & 3249 \\
\hline Useful models & 1205300 & 11906 \\
\hline
\end{tabular}

The specific feature of the intellectual rights turnover in the Russian Federation is the availability of a significant number of results of scientific and technical activities, transactions with which are made without taking into account the rules for handling protected results of intellectual property (RIP). First of all, these include all types of design, design and technological documentation (DTD). Under normal circumstances, such documents are formed at the end of the production and innovation cycle and are preceded by the stages of identification, accounting and protection of intellectual property. If the procedures have not been violated, by the time the DTD were made for the product all major technical solutions and innovations are already protected in the form of know-how and are reflected in the submitted patent applications. Therefore, the object of the transaction on transfer of technologies is the right to use this RID, and not the DTD as one of the forms of expression and implementation of this technical solution.

In these circumstances, disclosure or unauthorized use of the DTD is not a problem, as it may lead to infringement of the patent or know-how regime by granting the right holder appropriate possibilities for the protection of his/her rights. But in many engineering industries (aircraft building, engine building, machine building, power engineering) special measures to protect intellectual property are not taken in the presence of transactions with DTD, including" license agreements" and "lease agreements". This situation is also evidenced by a fairly significant number of disputes in local courts about the use of documentation.

In fact, parallel to the "official" circulation of rights to inventions, useful models and industrial designs, there is also an informal or "gray" circulation of documentation that does not fall into the statistical and registration records, the rules of which are determined only by the terms of transactions entered into by the parties. Courts take such conditions into account, considering concluded transactions valid and enforceable. The only way to legalize the use of such documentation is to try to introduce IP rights of the so-called "single technologies", which proved to be unsuccessful.

Another feature of the Russian IP market is the presence of significant volumes of scientific achievements of the USSR, inventory and accounting of the latter within the framework of Federal Agency for Scientific Organizations was started only in 2016. Unaccounted and unvalued achievements of the Soviet science turn to be at the disposal of quite autonomous scientific institutions, who sell them on an "informal" market to private entrepreneurs with no legal protection whatsoever, let alone the protection of intellectual property. The problem is compounded by the fact that these private partners, having no sufficient 
competence and resources, allow further leakage of such results without their successful implementation.

An integral and very important element of the IP market infrastructure is the availability of a sufficient number of professional consultants. At the beginning of 2016, 1763 active patent attorneys were registered in the Russian Federation. To compare with the following facts: Germany provides 3543 consultants, the USA accounts 33803 consultants.

Close integration of capital market with intellectual property market implies effective management of the value of the enterprise as a whole as well as its intangible assets, including intellectual property. In this aspect, raising debt funds for the purpose of business expansion and development, including secured by the company's intellectual property objects, comes into the picture.

\section{Discussion}

Entrepreneurs in many foreign countries have the opportunity to raise funds secured by various intellectual property objects. The number of registered intellectual property objects (IPO) pledge agreements in the world is increasing. In 2010 there were 4276 IPO pledge agreements, and in 2018 this number increased up to 5417. In Russia, the scale of using IPO as collateral is much lower: in 2018, only 85 pledge agreements were concluded.

The following objective reasons for the insufficient use of IPO as means of collateral can be distinguished:

- poor regulatory framework regarding the use of IPO as collateral;

- low level of development of the intellectual property market;

- no government support regarding the use of IPO as collateral;

- underestimation by borrowers and creditors of the importance and role of intellectual property as the genetic basis of business in modern conditions and the subject of pledge;

- low level of qualification of appraisers and bank employees for effective use of IPO as collateral;

- lack of experience regarding the use of IPO as collateral.

Thus, the problem of regulatory barriers in the field of credits secured by intellectual property and underdevelopment of the market of professional expertise of patentability are interrelated.

Here, two initiatives aimed at development of credits secured by intellectual property should be noted.

First, ANO "Digital Economy" working group on statutory regulation supported and included proposals of the Federation of Intellectual Property (FIS) to the draft of the federal project of the National Program "Digital Economy" on drafting a bill on credits secured by intellectual property.

The Federation of Intellectual Property (FIS) has earlier proposed to include a number of bills important for development of the intellectual property market to the "road map" of regulatory and legal regulation of the digital economy. The proposals, in particular, relate to removal of restrictions for the banks to set aside funds for giving credits secured by the objects of intellectual property, the extension of the "tax amnesty" on income tax while creating intangible assets by Russian companies, the removal of barriers preventing professional patent expertise market from development, and a number of other measures. The plan of actions of the program "Digital Economy" also included FIS initiatives to establish a higher costs write-off rate for purchasing the rights to inventions, useful models and industrial designs from their creator under license agreements.

A second important initiative aimed at development of credits secured by intellectual property was presented for the project called "SMEs and Individual Entrepreneurship Support". Within the framework of the national project, the Government of the Russian Federa- 
tion plans from 2019 to 2024 to allocate 31 billion rubles to provide credits to small and medium-sized businesses (SMEs), secured by intellectual property rights. This information is stated in the passport of the national project "SMEs and Individual Entrepreneurship Support". The project supposes to provide credits secured by the objects of intellectual property to small and medium-sized businesses.

The passport of the national project specifies the following sums to be allocated for each subsequent year from the total sum of 31 billion rubles: 2019 - 1 billion rubles, 2020 2 billion rubles, 2021 - 4 billion rubles, 2022 - 6 billion rubles, 2023 - 8 billion rubles, 2024 - 10 billion rubles.

\section{Conclusion}

In the course of the study, it was proved that domestic digital economy's development inspires the demand for using intellectual property as collateral. Recent legislative initiatives are aimed at developing the methodological basis for assessing intellectual property as collateral and intensifying the use of intellectual property objects as collateral.

Thus, intellectual property is a specific economic category, created as a result of intellectual activity and is, as a rule, intangible. As part of the process of digitalization of economy, the organizational structures and business models of companies are being significantly reformatted, and intangible assets, including intellectual property are beginning to play an increasingly important role in the activities of enterprises. Domestic economy's digitalization also inspires the growth of interest of enterprises to use intellectual property objects both directly in the production process, and as a tool for attracting funds. At the same time, there is a number of regulatory and organizational barriers preventing intellectual property from being used as collateral. The latest legislative initiatives are aimed at overcoming these barriers and developing the use of intellectual property as collateral.

Logistic approach suggests the integrating methods for solving the problem of integrating material and financial flows with further research considering the synthesis of models for managing material and financial flows.

\section{References}

1. N. Komninos, Intelligent Cities: Innovation, knowledge systems and digital spaces. (Taylor \& Francis, London and New York, 2002)

2. N. Komninos, Intelligent Cities and Globalisation of Innovation Networks. (Routledge, London and New York, 2008)

3. A. Zaleski, «GE's first 3D-printed parts take fight», FORTUNE, 12(5) (2015)

4. H. Schaffers, N. Komninos, M. Pallot, B. Trousse, M. Nilsson, A. Oliveira, Smart Cities and the Future Internet: Towards Cooperation Frameworks for Open Innovation. The Future Internet Assembly, LNCS6656, 431- 446 (2011).

5. N. Kroes, European Commissioner for Digital agenda, The critical role of cities in making the Digital Agenda a reality. Closing speech to Global Cities Dialogue Spring Summit of Mayors Brussels, 28(5) (2010). 
6. A. Caragliu, C. Del Bo, P. Nijkamp, Smart cities in Europe. Series Research Memoranda 0048. VU University Amsterdam, Faculty of Economics, Business Administration and Econometrics (2009)

7. S. P. Mohanty, U. Choppali, E. Kougianos, Everything you wanted to know about smart cities. IEEE Consumer Electronics Magazine; (7), 60-70 (2016)

8. S. J. Wang, P. Moriarty, Big data for urban sustainability: A human-centered perspective. New York: Springer (2018).

9. L. Kleerekoper, M. van Esch, T. B., Salcedo How to make a city climate-proof, addressing the urban heat island effect. Resources, Conserv \& Recycling; (64), 30-38 (2012).

10. International Council for Local Environmental Initiatives (ICLEI) (2017). http://www.sustainable.org/creating-community/inventories-and-indicators/149-

international-council-for-local-environmental-initiatives-iclei (last accessed 04.03.2019)

11. H. Singh, An effective \& resourceful contribution of green banking towards sustainability [Text], H. Singh, B.P. Singh, International j. of advances in engineering science and technology. (1)2, 41-45 (2013)

12. World Intellectual Property Indicators 2018. http://www.wipo.int/edocs/pubdocs/en/wipo_pub_941_2018.pdf (last accessed 01.02.2019)

13. I. Aleksandrov, M. Fedorova, MATEC, 170, $01011 \quad$ (2018) doi.org/10.1051/matecconf/201817001011

14. S. E. Barykin, "Logistic management methodology of corporation financing" Audit and Financial Analysis, 5, 330-348 (2007).

15. O. Kalinina, E. Balchik, S. Barykin (2018), Innovative management neural network modelling based on logistic theory. MATEC, 239, 04021 (2018). doi.org/10.1051/matecconf $/ 201823904021$

16. I. Ilin, O. Kalinina, S. Barykin, Financial logistics innovations in IT Project Management. MATEC, 193, 05062 (2018). doi.org/10.1051/matecconf/201819305062 